\title{
PEMBINAAN TENAGA REKRUITMEN DONOR DARAH DALAM RANGKA MENCEGAH INFEKSI MENULAR MELALUI TRANSFUSI DARAH DI KOTA BENGKULU
}

\section{THE TRAINING OF BLOOD DONOR RECRUITMENT PERSONNEL IN ORDER TO PREVENT SPREAD INFECTION THROUGH BLOOD TRANSFUSION IN BENGKULU CITY}

\author{
Oleh: \\ Dessy Trianal, Elvira Rosana ${ }^{2}$, Meutia Arini Yasrizal $^{3}$ \\ ${ }^{1}$ Departemen Parasitologi Fakultas Kedokteran dan Ilmu Kesehatan Universitas Bengkulu \\ ${ }^{2}$ Departemen Biologi dan Imunologi Fakultas Kedokteran dan Ilmu Kesehatan Universitas \\ Bengkulu \\ ${ }^{3}$ Departemen Patologi Klinik Fakultas Kedokteran dan Ilmu Kesehatan Universitas \\ Bengkulu \\ E-mail: dessy.triana13@gmail.com
}

\begin{abstract}
The high rates of Transfusion-Transmitted Infections (TTI) in Indonesia, especially in Bengkulu Province is quite high and becoming a problem that must be tackled. As reported up to June 2012 the number of cumulative AIDS cases in Indonesia according to gender were 30.931 cases, while the cumulative number of HIV and AIDS as many as 611 cases on Bengkulu province. PMI Bengkulu City in 2015 found 61 cases of Hepatitis B, two cases of Hepatitis $C$ and Syphilis 29 cases. WHO Global Database on bloody Safety reported that $20 \%$ the population in developed countries as much as $80 \%$ have been using donor blood safely, while $80 \%$ of the world's population circulating in developing countries only $20 \%$ was safe. The training applies various methods of learning such as: interactive lectures, case related discussions, donor screening practices skills, pre-test and post-test with feedback training. The training was attended by 14 donor recruitment personnel of UTD PMI Bengkulu with most age range 31 to 40 years old, most of them high school have education level and they have less knowledge and skill. In addition, ongoing education and up-to-date information regarding infectious agent that are potentially transmitted via blood components are crucial for protecting TTI.
\end{abstract}

Keywords: blood transfusion, blood donor recruitment personnel

\section{PENDAHULUAN}

Transfusi darah secara universal dibutuhkan untuk menangani pasien anemia berat, pasien dengan kelaian darah bawaan, pasien yang mengalami kecederaan parah, pasien yang hendak menjalankan tindakan bedah operatif dan pasien yang mengalami penyakit liver ataupun penyakit lainnya yang mengakibatkan tubuh pasien tidak dapat memproduksi darah atau komponen darah sebagaimana mestinya. Pada negara berkembang, transfusi darah juga diperlukan untuk menangani kegawatdaruratan melahirkan dan anak-anak malnutrisi yang berujung pada anemia berat. Tanpa darah yang cukup, seseorang dapat mengalami gangguan kesehatan bahkan kematian. Oleh karena itu, tranfusi darah yang 
diberikan kepada pasien yang membutuhkannya sangat diperlukan untuk menyelamatkan jiwa (WHO, 2007).

Indonesia membutuhkan sedikitnya satu juta pendonor darah guna memenuhi kebutuhan 4,5 juta kantong darah per tahunnya. Unit Transfusi Darah Palang Merah Indonesia (UTD PMI) menyatakan bahwa pada tahun 2008 darah yang terkumpul sejumlah 1.283.582 kantong, sehingga menggambarkan bahwa kebutuhan akan darah di Indonesia yang tinggi tetapi darah yang terkumpul dari donor darah masih rendah dikarenakan tingkat kesadaran masyarakat Indonesia untuk menjadi pendonor darah sukarela masih rendah. Hal ini dapat disebabkan oleh beberapa kendala misalnya karena masih kurangnya pemahaman masyarakat tentang masalah transfusi darah, persepsi akan bahaya bila seseorang memberikan darah secara rutin. Selain itu, kegiatan donor darah juga terhambat oleh keterbatasan jumlah UTD PMI di berbagai daerah, PMI hanya mempunyai 188 UTD. Mengingat jumlah kota/kabupaten di Indonesia mencapai sekitar 440 (Dardjatun, 2008).

Transfusi darah berhubungan dengan kondisi medis seperti kehilangan darah dalam jumlah besar disebabkan perdarahan pasca melahirkan, trauma, operasi, demam berdarah, kelainan darah dan lainnya. Pemberian transfusi darah mempunyai risiko penularan penyakit Infeksi Menular Lewat Transfusi Darah (IMLTD) terutama HIV/AIDS, Hepatitis C, Hepatitis B, Sifilis, Malaria, Demam Berdarah Dengue (DBD) serta risiko transfusi lain yang dapat mengancam nyawa (Dodd et al., 2009; Garraud et al., 2006; WHO, 2011). Epidemiologi infeksi pada populasi di suatu negara dapat diminimalisir dengan melakukan transfusi darah yang aman. Sebagai contoh, di Inggris sebelum transfusi darah harus dilakukan skrining penyakit sifilis, hepatitis B, hepatitis $\mathrm{C}$, human T-lymphotropic virus type 1 (HTLV-1), HTLV-2 dan HIV. Apabila ada sejarah perjalanan maka ditambah dengan pemeriksaan antibodi terhadap malaria dan trypanosoma cruzi, antibodi cytomegalo virus (CMV) dan anti-HBc (Booth and Allard, 2017).

Tingginya angka penyakit infeksi yang ditularkan melalui transfusi darah di Indonesia khususnya di Provinsi Bengkulu yang cukup tinggi merupakan masalah yang harus segera ditangani. Dilaporkan sampai dengan Juni 2012 jumlah kumulatif kasus AIDS di Indonesia menurut jenis kelamin tercatat ada 30,931 kasus, sedangkan jumlah kumulatif HIV dan AIDS berdasarkan Provinsi Bengkulu sebanyak 611 kasus. WHO Global Database on bloody Safety melaporkan bahwa $20 \%$ populasi dunia berada di negara maju sebanyak $80 \%$ telah memakai darah donor yang aman, sedangkan $80 \%$ populasi dunia yang beredar di negara berkembang hanya $20 \%$ memakai darah donor yang aman (WHO, 2007).

Unit Transfusi Darah PMI berperan melakukan kegiatan surveilans atau pengamatan terhadap kasus-kasus infeksi yang penularannya salah satunya karena transfusi darah, dengan melakukan skrining atau penapisan darah donor melalui UTD PMI Kota Bengkulu. Tujuan skrining ini adalah untuk mengamankan darah donor agar bebas dari berbagai penyakit infeksi. Selain itu, mengupayakan dan menjamin seluruh darah serta komponen yang di donorkan telah memenuhi kualitas darah yang diperlukan penderita. Dalam pelaksanaan donor darah sangatlah penting bagi UTD PMI untuk selalu memantau kondisikondisi darah serta jumlah atau banyaknya darah yang dibutuhkan oleh pasien. Kegiatan ini bertujuan untuk memberikan pengetahuan dan pembinaan kepada para tenaga rekruitmen donor darah untuk mengenali dan memahami sumber-sumber infeksi yang menular sehingga Uji Saring IMLTD menjadi berkualitas.

Darah dan berbagai komponen darah dapat ditransfusikan secara terpisah sesuai dengan kebutuhan. Darah tersusun dari berbagai komponen yaitu darah merah pekat (Packed Red Cells/ PRC), buffy konsentrat trombosit (Thrombocyte Concentrate/ TC), 
plasma cair dan plasma segar beku (Fresh Frozen Plasma/ FFP) (Kementerian Kesehatan RI, 2014). Komponen darah yang ditransfusikan sesuai dengan yang diperlukan akan mengurangi kemungkinan terjadinya reaksi transfusi, circulatory overload dan penularan infeksi yang terjadi dibandingkan dengan transfusi darah lengkap (O 'brien et al., 2012).

Prinsip pelayanan transfusi darah yaitu: (1) darah berasal dari donor sukarela, sehat dan memenuhi kriteria sebagai donor risiko rendah terhadap tertular penyakit IMLTD, (2) seluruh proses pengamanan, pengelolahan dan penyimpanan serta kualitas bahan habis pakai sesuai standar, (3) distribusi dilakukan dengan rantai dingin oleh petugas yang berwenang serta mengikuti SOP, pemakaian secara rasional, (4) indikasi dan pemilihan komponen berdasarkan analisa medis yang tepat. Keputusan melakukan transfusi harus selalu berdasarkan penilaian yang tepat dari segi klinis penyakit dan hasil pemeriksaan laboratorium. Transfusi dapat mengakibatkan penyulit akut atau lambat dan membawa risiko transmisi infeksi antara lain HIV, hepatitis, sifilis, risiko supresi sistem imun tubuh serta risiko transfusi lain yang dapat mengancam nyawa. Transfusi yang aman bukan berarti dengan zero-risk tetapi mengikuti standar nasional dengan program akresitasi, pelatihan bagi tim medis dan tenaga rekrutmen donor serta sistem dan fasilitas sesuai dengan Good Manufacturing Practices (Klein, 2010). Faktor keamanan dan keefektifan transfusi bergantung pada 2 hal yaitu (1) tersedianya darah dan komponen darah yang aman, mudah didapat, harga terjangkau, dan jumlahnya cukup memenuhi kebutuhan nasional (2) indikasi transfusi darah dan komponen darah yang tepat (Australia Red Cross Blood Service, 2014).

Transfusi darah merupakan jalur ideal bagi penularan infeksi tertentu dari donor kepada resipien. Upaya untuk mengurangi potensi transmisi penyakit melalui transfusi darah, maka diperlukan skrining terhadap faktor-faktor risiko yang dimulai dari riwayat medis sampai beberapa tes spesifik. Tujuan utama skrining adalah untuk memastikan agar persediaan darah didapatkan bebas dari penyebab infeksi dengan cara melacaknya sebelum darah tersebut ditransfusikan (Ceccherini-Nelli et al., 2004). Saat ini, terdapat tiga jenis utama skrining yang tersedia untuk melacak penyebab infeksi,yaitu: uji Enzyme Linked Immuno Sorbent Assay (ELISA/ EIA), uji aglutinasi partikel, dan uji cepat khusus (Rapid Test). Dalam berbagai pengujian, perlu dipertimbangkan data yang berkaitan dengan sensitifitas dan spesifitas masing-masing pengujian. Sensitifitas adalah suatu kemungkinan adanya hasil tes yang akan menjadi reaktif pada seorang individu yang terinfeksi, oleh karena itu sensitifitas pada suatu pengujian adalah kemampuannya untuk melacak sampel positif yang selemah mungkin. Spesifisitas adalah suatu kemungkinan adanya suatu hasil tes yang menjadi non-reaktif pada seorang individu yang tidak terinfeksi, oleh karena itu spesifitas suatu pengujian adalah kemampuannya untuk melacak hasil positif non-spesifik atau palsu (Allard, 2013).

Tujuan dari kegiatan ini adalah:

1. Memberikan pengetahuan pada tenaga rekruitmen donor darah agar dapat meakukan deteksi dini untuk mencegah terjadinya transmisi penyakit.

2. Memberikan keterampilan pada tenaga rekruitmen donor darah agar dapat melakukan deteksi dini untuk mencegah terjadinya penularan penyakit infeksi dan dapat menjadi upaya skrining yang berkelanjutan terkait pencegahan transmisi penyakit.

Manfaat dari kegiatan ini adalah:

1. Mendukung program pemerintah manajemen mutu pada setiap tahap kegiatan pelayanan darah. 
2. Menjaring sejak awal untuk menurunkan risiko proses pengadaan darah terhadap kontaminasi, pencampuran, transmisi penyakit atau efek tak terduga lainnya akibat penggunaan darah.

3. Melakukan penyegaran kepada tenaga rekruitmen donor darah terhadap tahapan seleksi donor dan pemeriksaan pre transfusi.

\section{METODE PENGABDIAN}

Metode kegiatan dilakukan dengan memberikan pelatihan langsung pada tenaga rekruitmen donor untuk melakukan skrining donor dan standar uji saring IMLTD. Pelatihan ini dilakukan dengan berbagai metoda belajar yaitu:

1. Kuliah interaktif mengenai skrining donor dan standar uji saring infeksi menular melalui transfusi darah.

2. Diskusi tentang kasus-kasus terkait skrining donor dan standar uji saring infeksi menular melalui transfusi darah.

3. Praktik keterampilan skrining donor dan standar uji saring infeksi menular melalui transfusi darah melalui form kuesioner dan informed consent.

4. Pre test dan post test serta umpan balik pelatihan.

\section{HASIL DAN PEMBAHASAN}

Pelatihan ini dilaksanakan di UTD PMI Kota Bengkulu yang terletak di RSUD Dr. M. Yunus Bengkulu pada tanggal 27 Agustus 2016 pukul 09.00 s.d 15.00 WIB dan diikuti 14 peserta. Peserta pelatihan dan pembinaan adalah sebagai berikut:

Tabel 1. Peserta pelatihan dan pembinaan skrining donor dan standar uji saring IMLTD

\begin{tabular}{ccccccc}
\hline No. & Nama & Umur (tahun) & Pendidikan & Masa Kerja (tahun) & Nilai Pre Test & Nilai Post Test \\
\hline 1 & RM & 26 & PTTD & 6 & 40 & 60 \\
2 & MH & 37 & D3 & 11 & 50 & 60 \\
3 & Y & 38 & SMAK & 18 & 60 & 60 \\
4 & NS & 34 & SMU & 10 & 60 & 70 \\
5 & N & 41 & S1 & 21 & 60 & 70 \\
6 & OM & 60 & ATD & 36 & 60 & 70 \\
7 & IN & 31 & PTTD & 0 & 60 & 70 \\
8 & AW & 24 & PTTD & 5 & 50 & 70 \\
9 & HM & 26 & D3 & 5 & 50 & 60 \\
10 & BU & 48 & ATD & 27 & 70 & 90 \\
11 & EA & 37 & SMA & 5 & 40 & 60 \\
12 & AR & 42 & SMA & 8 & 50 & 70 \\
13 & MY & 52 & SMA & 18 & 50 & 70 \\
14 & HA & 29 & SMA & 3 & 40 & 50 \\
\hline \multicolumn{7}{l}{ Jumlah } \\
Rata-rata
\end{tabular}


Evaluasi yang dilakukan adalah pengetahuan dan keterampilan dalam melakukan skrining donor dan uji saring IMLTD dengan cara rapid test yang memiliki beberapa kelemahan sehingga pengetahuan dan keterampilan anamnesis dan pemeriksaan fisik yang dilakukan oleh tenaga rekrutmen donor harus meminimalisir risiko IMLTD yang terjadi. Jenjang pendidikan terakhir dari terbanyak dari tenaga rekrutmen donor adalah SMA (36\%) dan rentang usia terbanyak 31 s.d 40 tahun (36\%) sehingga diperlukan pelatihan berkesinambungan untuk meningkatkan pengetahuan dan keterampilan dari tenaga rekrutmen donor ini karena mereka memiliki semangat untuk meningkatkan pengetahuan dan keterampilan dan merupakan lini terdepan dalam meminimalisir IMLTD.

Materi yang dievaluasi adalah tentang aturan terbaru tentang transfusi darah, pengawasan produk darah, pengujian laboratorium, kriteria seleksi donor, kondisi penolakan donor sementara dan tetap serta tahapan seleksi donor. Lamanya pengalaman kerja tidak memberikan dampak signifikan terhadap pengetahuan namun memberikan dampak yang cukup signifikan terhadap keterampilan dalam seleksi donor. Kekurangan secara umum adalah keterampilan dalam anamnesis yang seharusnya dilakukan oleh dokter tetapi dengan keterbatasan jumlah dokter maka tenaga rekrutmen donor juga melakukan anamnesis ini.

Evaluasi kegiatan ini dilakukan setelah pelatihan selesai dilakukan, indikator keberhasilan kegiatan ini terdapat peningkatan pengetahuan dan keterampilan dalam melakukan skrining donor dan uji saring IMLTD dan dilakukan evalausi kembali 1 ming gu kemudian. Hasil evaluasi ini diberikan kepada UTD PMI Kota Bengkulu untuk memperkuat pemahaman dan keterampilan tenaga rekrutmen donor terhadap materi yang dianggap sulit oleh tenaga rekrutmen donor.

\section{KESIMPULAN DAN SARAN}

\section{Kesimpulan}

Kesimpulan yang diperoleh dari kegiatan ini adalah: Jenjang pendidikan terakhir terbanyak dari tenaga rekrutmen donor adalah SMA sehingga diperlukan pelatihan berkesinambungan untuk meningkatkan pengetahuan dan keterampilan dari tenaga rekrutmen donor untuk perbaikan yang terus menerus dalam pelaksanaan seleksi donor, tes skrining yang sensitif dan prosedur inaktivasi yang efektif dapat memastikan penghapusan atau setidaknya pengurangan risiko IMLTD karena mereka merupakan lini terdepan dalam meminimalisir IMLTD.

\section{Saran}

Penambahan jumlah waktu pelatihan untuk pendidikan berkelanjutan dan informasi terbaru mengenai agen infeksi yang berpotensi menular melalui komponen darah yang diperlukan untuk mempromosikan pelaporan efek samping dalam transfusi darah.

\section{DAFTAR PUSTAKA}

Allard, S., 2013, Blood transfusion, Medicine, Vol. 41: 242-247.

Australia Red Cross Blood Service, 2014, Guidelines for the Selection of Blood Donors, Australia.

Booth, C., and Allard S., 2017. Blood transfusion, Medicine, Vol. 45(4): 244-250. 
Ceccherini-Nelli, L, Filipponi F, Mosca F, and Campa M, 2004, The Risk of Contracting an Infectious Disease From Blood Transfusion, Transplantation Proceedings, Elsevier Inc, New York, Vol. 36: 680-682.

Daradjatun, A., 2008, Keberadaan UTD di Indonesia, Palang Merah Indonesia (PMI), Jakarta.

Dodd, R., Roth W.K, Ashford P., M Dax E., and V yas G., 2009, Transfusion medicine and safety, Biologicals, Vol. 37: 62-70.

Garraud, O., Filho L.A., Laperche S., Tayou-Tagny C., and Pozzetto B., 2016, The infectious risks in blood transfusion as of today-A no black and white situation, La Presse Medicale, Vol. 45: 303-311.

Kementerian Kesehatan RI., 2014, Peraturan Menteri Kesehatan RI Nomor 83 Tahun 2014 Tentang Unit Transfusi Darah, Bank Darah Rumah Sakit dan Jejaring Pelayanan Transfusi Darah, Jakarta.

Klein, H.G., 2010, How safe is blood, really?, Biologicals, Vol. 38: 100-104.

O 'brien, S.F., Zou S., Laperche S., Brant L.J., Seed C.R., and Kleinman S.H., 2012, Surveillance of Transfusion-Transmissible Infections: Comparison of Systems in Five Developed Countries, Transfusion Medicine Reviews, Vol. 26: 38-57.

World Health Organization (WHO), 2007, Blood Transfusion Safety, WHO, Geneva.

World Health Organization (WHO), 2011, Guidelines on Good Manufacturing Practices for Blood Establishment. WHO Technical Report Series Number 961, WHO, Geneva. 